\title{
Genç Yetişkinlerde Yalnızlığın Yordayıcıları: Depresyon, Kaygı, Sosyal Destek, Duygusal Zeka
}

\author{
Hüdanur ÖZDEMIR ${ }^{1}$, Arkun TATAR ${ }^{2}$
}

\begin{abstract}
Özet: $\mathrm{Bu}$ çalışmada, genç yetişkinlerde yalnızlığın yordayıcısı olan olguların belirlenmesi amaçlanmıştır. Bu doğrultuda önce, yalnızlık, depresyon, kaygı, algılanan sosyal destek ve duygusal zeka arası ilişkiler incelenmiş, daha sonra farklı sosyo-demografik grupların yalnızlık puanları karşılaştırılmıştır. Çalışmaya, 18-25 yaş aralığında 213 kadın ve 226 erkek olmak üzere toplamda 439 kişi katılmıştır. İlk aşamada, tüm grupta yalnızlık puanının yordanması için çoklu doğrusal regresyon analizi yapılmış, analizler katılımcıların sosyo-demografik özelliklerine göre oluşturulan gruplar için ayrı ayrı olacak şekilde tekrar edilmiştir. Sonuçlara göre, tüm grupta Durumluk Kayg1, Sürekli Kayg1, CES Depresyon Ölçeği, UKMH Duygusal Zeka Testi'nin "Olumlu İfade” alt boyutu ve Çok Boyutlu Algılanan Sosyal Destek Ölçeği “Arkadaş” alt boyutu toplam puanı UCLA Yalnızlık Ölçeği toplam puanını \%66,0 oranında yordamaktadır. Çalışmada sonraki aşama olarak, farklı sosyo-demografik grupların yalnızlık puanları çok yönlü varyans analizi (ANOVA) ile karşılaştırılmış ve grupların yalnızlık puanları arasında anlamlı bir farklılık bulunmamıştır. Bununla birlikte, cinsiyet ve eğitim düzeyine göre oluşturulan gruplar arasında etkileşim olduğu görülmüştür.
\end{abstract}

Anahtar Kelimeler: yalnızlık, depresyon, kayg1, algılanan sosyal destek, duygusal zeka

\section{Predictors of Loneliness in Young Adults: Depression, Anxiety, Social Support, Emotional Intelligence}

\begin{abstract}
The present study aimed to determine the constructs that predict loneliness in young adults. For this purpose, the relations between loneliness, depression, anxiety, perceived social support and emotional intelligence were examined, and loneliness scores of different socio-demographic groups were compared. The study conducted with 213 female and 226 male, a total of 439 participants between the ages of 18 and 25 . In the first place, multiple linear regression analysis was performed in order to predict loneliness scores in the whole group, and the regression analysis was repeated in different groups which were generated based on the sociodemographic characteristics of the participants. Results of the regression analysis showed that State Anxiety, Trait Anxiety, CES Depression Scale, Positive Expressivity subscale of the IPIP Emotional Intelligence Test, and Friend subscale of the Multidimensional Perceived Social Support Scale predicted total score of the UCLA Loneliness Scale significantly; the prediction ratio for the loneliness was calculated 66.0\%. Afterwards, loneliness scores of different socio-demographic groups were compared using multi-way analysis of variance (ANOVA), and no significant differences were found between the groups. In addition, there was significant interaction observed between groups that were generated based on gender and education level.
\end{abstract}

Key Words: loneliness, depression, anxiety, perceived social support, emotional intelligence

${ }^{1}$ Psk., FSM Vakıf Üniversitesi, Klinik Psikoloji Yüksek Lisans Programı, İstanbul Türkiye. Email: hudaozdemir@gmail.com

${ }^{2}$ Doç. Dr., FSM Vakıf Üniversitesi, Edebiyat Fakültesi, Psikoloji Bölümü, İstanbul-Türkiye

Address of correspondence / Yazışma adresi: Hüdanur Özdemir, FSM Vakıf Üniversitesi, Klinik Psikoloji Yüksek Lisans Programı, İstanbul-Türkiye. E-mail: hudaozdemir@gmail.com

Date of received/ Geliş Tarihi:15.06.2019, Date of acceptance/ Kabul Tarihi: 27.07.201

Citing/ Referans Gösterimi:Özdemir H. \& Tatar, A., (2019). Genç Yetişkinlerde Yalnızlı̆̆ın Yordayıcıları: Depresyon, Kaygı, Sosyal Destek, Duygusal Zeka. Klbrıs Türk Psikiyatri ve Psikoloji Dergisi, 1 (2): 93-101 doi:10.35365/ctjpp.19.1.11 


\section{Giriş}

Yalnızlık kavramı, bireyin, sahip olduğu sosyal çevrenin genişliği ve kalitesine ilişkin öznel algısı ile sahip olmayı arzu ettiği sosyal çevrenin nitelik ve nicelik açısından tatmin edici düzeyde örtüşmemesi durumunda yaşadığ 1 olumsuz deneyimlere işaret etmektedir (Lee ve Ko, 2018; Perlman ve Peplau, 1984; Russell, Cutrona, McRae ve Gomez, 2012). Bazı bireyler sosyal çevrelerinden belirgin bir şekilde soyutlanmış olmalarına rağmen kendilerini yalnız hissetmediklerini, bazıları ise kişiler arası etkileşim açısından zengin bir sosyal çevreye sahip olmalarına rağmen kendilerini yalnız hissettiklerini belirtmektedirler (Lykes ve Kemmelmeier, 2014). Yalnızlık deneyimlerinde görülen bu türden bireysel ve durumsal farklılıklar, yalnızlığın çok boyutlu bir yapıya sahip olduğunu göstermektedir (Rokach, 2001; 2012). Bu bağlamda yalnızlığın kavramsallaştırılmasında üç temel bileşen üzerinde durulmaktadır. En temel bileşen, kişiler arası ilişkilerde yakın bağlanmanın bulunmamasından kaynaklı olarak oluşan yoksunluk durumudur. Bireylerin zaman perspektifleriyle ilişkili olan ikinci bileşen, geleceğe yönelik iyimser/ kötümser yorumları ve yalnızlık durumunun zaman içerisinde geçip geçmeyeceğine ilişkin öznel değerlendirmeleri içermektedir. Üçüncü bileşen ise üzüntü, keder, suçluluk, utanç, hayal kırıklığı, umutsuzluk gibi duygusal deneyimleri kapsamaktadır (de Jong-Gierveld, 1987; 1998; de Jong-Giervald ve van Tilburg, 2006a).

Yalnızlı̆̆ı açıklamaya ve ölçümünü gerçekleştirmeye yönelik olarak ortaya konulan modellerde içsel, gelişimsel ve durumsal yalnızlık olmak üzere üç farklı yalnızlık türü tanımlanmaktadır (Tiwari, 2013). İçsel yalnızlık, kişilik özellikleri, kontrol odağı, benlik saygısı, suçluluk hissi ve başa-çıkma stratejileriyle ilişkilidir. Gelişimsel yalnızlık, kişisel yetersizlikler, gelişimsel bozukluklar, zihinsel / fiziksel engeller, yaşam şartları ve yoksulluk gibi faktörlerle ilişkilidir. Durumsal yalnızlık ise kişiler arası çatışmalar, göçler, kazalar, felaketler ve diğer çevresel faktörlerle ilişkilidir (Mushtaq, Shoib, Shah ve Mushtaq, 2014). Yalnızlığın açıklanmasında diğer bir sınıflamayı ise sosyal yalnızlık ve duygusal yalnızlık oluşturmaktadır (Weiss, 1973). Sosyal yalnızlık sosyal iletişim ağının (social network) yetersizliğinden kaynaklanan sosyal izolasyonu, duygusal yalnızlı ise bağlanma nesnesinin/ figürünün yokluğundan kaynaklanan hoşnutsuzluk duygusunu ifade etmektedir (de Jong-Gierveld ve van Tilburg, 2006b; 2008; Lee ve Ko, 2018; Perlman ve Peplau, 1981).

Yalnızlık (loneliness) olgusunu, sosyal bir ortamda tek başına (alone) olmaktan ayıran en önemli faktör, yalnızlığın, temelde birey tarafindan istenmeyen bir durum olarak algılanması ve sosyal izolasyon sürecine olumsuz duyguların eşlik etmesidir (van Winkel ve ark., 2017). Bu yönüyle yalnızlık, depresyon ve kaygıya yatkınlık oluşturmakta, bilişsel işlevlerde zayıflamaya yol açmakta ve ölüm riskini arttırmaktadır (Lee ve Ko, 2018). Diğer insanlarla ilişki kurmada ve kişiler arası ilişkileri sağlıklı bir şekilde sürdürmede güçlük çeken, problem çözme becerileri zayıf, benlik algısı tutarsız ve benlik saygısı düşük olan bireylerin daha yalnız hissettikleri, bu nedenle de özellikle depresyon ve kaygı açısından daha kırılgan (vulnerable) oldukları belirtilmektedir (Mushtaq ve ark., 2014). Ayrica, yalnız bireylerde depresyon ve kaygı semptomları daha yoğun olarak görülmekte ve bu kişiler diğer insanlara oranla daha mutsuz, üzgün ve çaresiz hissetmektedirler (Singh ve Misra, 2009). Diğer taraftan, algılanan sosyal destek düzeyinin artmasına bağlı olarak algılanan yalnızlık düzeyi azalmakta ve gelecekte her şeyin daha iyi olacağına ilişkin iyimserlik düzeyi de artış göstermektedir (Alpass ve Neville, 2003; Daniel, 2013; Ozsaker, Muslu, Kahraman, Beytut, Yardimci ve Basbakkal, 2015; van Winkel ve ark., 2017). Bununla birlikte, kişiler arası etkileşim sürecinde ortaya çıkan duygusal deneyimler de algılanan yalnızlık düzeyi üzerinde belirleyici bir etkiye sahiptir. Bu bağlamda, yalnızlığın, duygusal zeka ve pozitif duygulanım ile ters, aleksitimi ile pozitif yönde ilişki gösterdiği bildirilmektedir (Lee ve Ko, 2018; Saklofske, Austin ve Minski, 2003).

Yalnızlığın açıklanması ve ilişkili olduğu yapıların belirlenmesi amacıyla yapılan pek çok çalışmanın genel olarak çocukluk, ergenlik ve ileri yetişkinlik dönemlerine odaklandığı ve mevcut araştırmaların çoğunlukla çocuklardan, ergenlerden ve yaşlılardan oluşan örneklem gruplarıyla yürütüldüğü görülmektedir (Besevegis ve Galanaki, 2010; Demir ve Tarhan, 2001; Eskin, 2001; Houghton, Hattie, Wood, Carroll, Martin ve Tan, 2014; Kang, Park ve Wallace, 2018; Mahon, Yarcheski, Yarcheski, Cannella ve Hanks, 2006; Seepersad, 2004; Spence, Jacobs ve Bifulco, 2018). Buna karşın erken yetişkinlik döneminde yalnızlığı açıklamaya yönelik görece daha az sayıda betimsel çalışma bulunmaktadır (Cooper, Balandin ve Trembath, 2009; Kafetsios ve Sideridis, 2006; Le Prevost ve ark., 2018; Ozsaker ve ark., 2015; Qualter, Vanhalst, Harris, Van Roekel, Lodder, Bangee ve ark., 2015; Rokach, 2005). Bu doğrultuda bu çalışma kaygı, depresyon, algılanan sosyal destek ve duygusal zeka ile yalnızlık arasındaki ilişkilerin genç yetişkinlerden oluşan örneklem grubunda incelenmesi amacıyla yürütülmüştür. Bu amaçla, söz konusu olguların genç yetişkinlerde yalnızlığı ne oranda açıkladığının belirlenmesi ve farklı sosyo-demografik özelliklere göre oluşturulan grupların yalnızlı düzeylerinin karşılaştırılması planlanmıştır.

\section{Yöntem}

\section{Katılımcılar}

Çalışmaya 213'ü kadın $(\% 48,5)$ ve 226'sı $(\% 51,5)$ erkek olmak üzere 18-25 yaşları arasında 439 kişi katılmıştır. Kat1lımc1ların 100'ü $(\% 22,8)$ lise ve altı düzeylerde, 339'u $(\% 77,2)$ ise üniversite düzeyinde eğitim gördüğünü; 321'i $(\% 73,1)$ öğrenci olduğunu, 77'si $(\% 17,5)$ gelir getiren bir işte çalıştığını ve 41 'i $(\% 9,3)$ gelir getiren herhangi bir işte çalışmadığını; 423'ü bekar $(\% 96,4)$ ve 15 'i $(\% 3,4)$ evli olduğunu; 358'i $(\% 81,5)$ yaşamının büyük bir bölümünü il / büyükşehirde geçirdiğini, 81'i $(\% 18,5)$ ise yaşamının büyük bir bölümünü kasaba / ilçe veya köyde geçirdiğini bildirmiştir. Ayrıca katılımcıların 97'si $(\% 22,1) 2$ ve daha az sayıda kişi, 129'u (\%29,4) 3 kişi, 108'i $(\% 24,6) 4$ kişi ve 99 'u $(\% 22,6) 5$ ve daha fazla sayıda kişi ile aynı evde birlikte yaşadıklarını bildirmişlerdir. Soruyu cevaplamayan kişi sayısı ise 6'dır $(\% 1,4)$.

\section{Gereçler}

Çalışmada UCLA Yalnızlık Ölçeği, Uluslararası Kişilik Madde Havuzu-Duygusal Zeka Testi (UKMH-DZT), Durumluluk-Sürekli Kaygı Ölçeği, CES Depresyon Ölçeği ve Çok Boyutlu Algıllanan Sosyal Destek Ölçeği 
ile birlikte katılımcıların sosyo-demografik özelliklerini belirlemek amaciyla hazırlanan anket formu uygulanmıştır.

UCLA Yalnızlık Ölçeği-Gözden Geçirilmiş Formu, 4'lü Likert tipi (1 = Ben Bu Durumu Hiç Yaşamadım, 4 = Ben Bu Durumu Sık Sik Yaşarım) cevaplama seçeneği içeren 20 maddeden oluşmaktadır (Russell, Peplau ve Cutrona, 1980). Ölçekten elde edilen yüksek puan, yalnızlık duygusunun yoğun yaşandığını göstermektedir. Türkçeye çeviri çalışmasında UCLA Yalnızlık Ölçeği gözden geçirilmiş Türkçe formu için 0,96 düzeyinde Cronbach Alfa iç tutarlılık güvenirlik katsayısı hesaplandığı bildirilmiştir (Demir, 1989). Ayrıca, kriter bağıntılı geçerlik kapsamında UCLA Yalnızlık Ölçeği toplam puanının, Beck Depresyon Envanteri toplam puanı ile 0,77 ve Çok Yönlü Depresyon Envanteri Sosyal İçedönüklük alt ölçeği toplam puanı ile 0,82 düzeyinde ilişkili olduğu bildirilmiştir (Demir, 1989).

Durumluluk - Sürekli Kaygı Envanteri, 4'lü Likert tipi cevaplama seçeneği içeren ( $1=$ Hiç, $4=$ Tamamen $) 40$ maddeden oluşmaktadır. Envanterin 20 maddelik ilk yarısı durumluk kaygıyı, 20 maddelik ikinci yarısı ise sürekli kaygıyı değerlendirmektedir. Durumluk Kayg1 Ölçeği'nin maddelerinden 10'u, Sürekli Kaygı Ölçeği'nin maddelerinden 7'si ters yönlü olarak puanlanmaktadır. Her iki ölçekten de 20-80 arasında toplam puan elde edilmektedir. Yüksek puanlar kaygı düzeyinin yüksekliğine işaret etmektedir (Spielberger, Gorsuch ve Lushene, 1970). Envanterin Türkçeye çeviri çalışmasında, Durumluk Kaygı Ölçeği için 0,94 ile 0,96 ve Sürekli Kayg1 Ölçeği için 0,83 ile 0,87 arasında değişen düzeylerde iç tutarlılık güvenirlik katsayıları hesaplandığı bildirilmiştir. Bunun yanı sıra asıl uygulamadan 10, 15, 30,120 ve 360 gün ara ile yürütülen test-tekrar test uygulamaları arasında Sürekli Kaygı Ölçeği için 0,71 ile 0,86 arasında, Durumluk Kaygı Ölçeği için 0,26 ile 0,68 arasında değişen düzeylerde korelasyon katsayısı hesaplandığı bildirilmiştir (Öner ve Le Compte, 1985).

CES Depresyon Ölçeği, 4'lü Likert tipi cevaplama seçeneği içeren $(0=$ Hiçbir Zaman-Nadiren, 3 = ÇokçaÇoğu Zaman) 20 maddeden oluşmaktadır. Ölçekten 0 ile 60 arasında toplam puan elde edilmekte, yüksek puan depresyon düzeyinin yüksekliğine işaret etmektedir (Radloff, 1977). Ölçeğin Türkçeye çeviri çalışması kapsamında yürütülen asıl uygulamada 0,84 , tekrar test uygulamasında 0,88 düzeyinde Cronbach Alfa iç tutarlılık güvenirlik katsayısı hesaplandığı bildirilmiştir. Bunun yanı sira iki uygulama arasında 0,69 düzeyinde ilişki olduğu belirtilmiştir. Ayrıca kriter bağıntılı geçerlik kapsamında, CES Depresyon Ölçeği ile Beck Depresyon Envanteri arasında 0,77 düzeyinde korelasyon katsayıs1 hesaplandığı bildirilmiştir (Tatar ve Saltukoğlu, 2010).

Uluslararası Kişilik Madde Havuzu Duygusal Zeka Testi (UKMH-DZT), 5'li Likert tipi cevaplama seçeneği içeren $(1=$ Hiç Uygun Değil, $5=$ Çok Uygun $) 68$ maddeden oluşmaktadır. Ölçekte "Duygulara Yaklaşım", "Duygu Temelli Karar Verme", "Empatik İlgi", "Olumsuz İfade (İfade Edicilik)", "Olumlu İfade (İfade Edicilik)", "Karşılık Olarak Üzüntü” ve "Karşılık Olarak Neşe" olmak üzere yedi alt boyut bulunmaktadır. UKMH Duygusal Zeka Testi'nden elde edilen yüksek puan, duygusal zeka düzeyinin yüksekliğini göstermektedir (Barchard, 2001; Tatar, Saltukoğlu, Tok ve Bender, 2016). Testin Türkçeye uyarlama çalışmasında, ilk uygulamada, testin bütünü için 0,86 ve alt boyutları için
0,57-0,71 arasında; tekrar test uygulamasında, testin bütünü için 0,89 ve alt boyutları için $0,60-0,81$ arasında Cronbach Alfa iç tutarlılık güvenirlik katsayıları hesaplandığı bildirilmiştir. Ayrıca, 15 gün ara ile gerçekleştirilen test-tekrar test uygulamaları arasında testin bütünü için 0,81 ve alt boyutları için $0,67-0,80$ arasında değişen düzeyde korelasyon katsayısı elde edildiği bildirilmiştir. Kriter bağıntılı geçerlik kapsamında ise UKMH Duygusal Zeka Testi genel toplam puanı ile Gözden Geçirilmiş Schutte Duygusal Zeka Ölçeği genel toplam puanı arasında 0,59 düzeyinde korelasyon katsayısı hesaplandığ belirtilmiştir (Tatar, Saltukoğlu, Tok ve Bender, 2016).

Çok Boyutlu Algılanan Sosyal Destek Ölçeği (ÇBASDÖ)-Gözden Geçirilmiş Formu, 7'li likert tipi cevaplama seçeneği içeren $(1=$ Kesinlikle Hayır, 7 = Kesinlikle Evet) 12 maddeden oluşmaktadır. Ölçekte yer alan "Aile", "Arkadaş" ve "Özel Bir İnsan" alt boyutları, algılanan sosyal desteğin kaynağına işaret etmektedir. Ölçekten 12-84 arasında toplam puan elde edilmekte ve yüksek puanlar algilanan sosyal destek düzeyinin yüksekliğini göstermektedir (Eker ve Arkar, 1995; Eker, Arkar ve Yaldı, 2001; Zimet, Dahlem, Zimet ve Farley, 1988) Ölçeğin Türkçeye çevirisinin gözden geçirildiği çalışmada ölçeğin bütünü için 0,89 , Aile alt boyutu için 0,85 , Arkadaş alt boyutu için 0,85 , Özel Bir İnsan alt boyutu için 0,92 düzeyinde Cronbach Alfa iç tutarlılık güvenirlik katsayısı hesaplandığı bildirilmiştir. Ayrıca, kriter bağıntılı geçerlik kapsamında, Çok Boyutlu Algılanan Sosyal Destek Ölçeği genel toplam puanının Beck Umutsuzluk Ölçeği ile -0,45, UCLA Yalnızlık Ölçeği ile -0,63, Aile ve Arkadaşlardan Algılanan Sosyal Destek Ölçeği (Eskin, 1993; Procidona ve Heler, 1983) Aile alt boyutu ile 0,61, Arkadaşlar alt boyutu ile 0,59 düzeyinde korelasyon gösterdiği bildirilmiştir (Eker, Arkar ve Yaldiz, 2001).

\section{Uygulama}

Çalışmanın uygulaması iki aylık bir süreç içerisinde kolay örnekleme yöntemi kullanılarak ulaşılan kişilerle İstanbul ilinde gerçekleştirilmiştir. Çalışmaya gönüllü olarak katılmayı kabul edenlere çalışma hakkında bilgi verildikten sonra, katılımcilardan "gönüllü olur" alınmıştır ve kimlik bilgisi alınmadan uygulama formları verilmiştir. Çalışmada dışlama kriteri olarak yaş alınmış, bu doğrultuda 18 yaşından küçük ve 25 yaşından büyük kişiler çalışmaya dahil edilmemiştir. Bir kişilik uygulama yaklaşık olarak 45-60 dakika sürmüştür.

\section{Verilerin Analizi}

Çalışmada ilk aşama olarak kullanılan ölçme araçlarından elde edilen puanların normal dağılıma uygunluğu Kolmogorov-Smirnov testi, betimleyici istatistik değerleri ve basıklık-çarpıklık (kurtosis-skewness) katsayılarının incelenmesi yoluyla belirlenmiştir. Daha sonra kullanılan ölçekler ve alt boyutları için Cronbach Alfa iç tutarlılık güvenirlik katsayısı hesaplanmıştır. İkinci aşamada ise çalışmanın temel amacını karşılamak üzere UCLA Yalnızlık Ölçeği toplam puanı ile diğer ölçeklerden elde edilen toplam puanlar arasındaki korelasyonlar belirlenmiş ve UCLA Yalnızlık Ölçeği toplam puanı, tüm grupta ve katılımciların sosyodemografik özelliklerine göre oluşturulan farklı bağımsız değişken gruplarında ayrı ayrı olacak şekilde çoklu doğrusal regresyon analiziyle yordanmıştır. Son işlem olarak ise sosyo-demografik değişken grupları, bir arada 
alınarak UCLA Yalnızlık Ölçeği toplam puanı açısından çok yönlü varyans analizi (ANOVA) ile karşılaştırılmıştır.

\section{Bulgular}

Çalışmada, öncelikle, kullanılan ölçekler için güvenirlik analizi yapılmış ve UCLA Yalnızlık Ölçeği için 0,90, Durumluk Kaygı Ölçeği için 0,89, Sürekli Kaygı Ölçeği için 0,84, CES Depresyon Ölçeği için 0,90, UKMH Duygusal Zeka Testi genel toplam puanı için 0,86 ve Çok Boyutlu Algilanan Sosyal Destek Ölçeği genel toplam puanı için 0,91 düzeyinde Cronbach Alfa iç tutarlılık güvenirlik katsayıları hesaplanmıştır. Ayrıca, UKMH Duygusal Zeka Testi alt boyut toplam puanları için 0,52 ile 0,71 ve Çok Boyutlu Algılanan Sosyal Destek Ölçeği

\section{Tablo 1. Kullanılan Ölçeklerin İç Tutarııık Güvenirlik ve UCLA Yalnızlık Öıçeği ile Korelasyon Analizi Sonuçları}

\begin{tabular}{lc}
\hline $\mathrm{n}=439$ & Cronbach Alfa \\
\hline UCLA Yalnılık Ölçeği & 0,90 \\
Durumluk Kaygı Ölçeği & 0,89 \\
Sürekli Kaygı Ölçeği & 0,84 \\
CES Depresyon Ölçeği & 0,90 \\
\hline UKMH-DZT Duygulara Yaklaşım Alt Boyutu & 0,64 \\
UKMH-DZT Duygu Temelli Karar Verme Alt Boyutu & 0,61 \\
UKMH-DZT Empatik İlgi Alt Boyutu & 0,52 \\
UKMH-DZT Olumsuz İfade (İfade Edicilik) Alt Boyutu & $0,63^{* * *}$ \\
UKMH-DZT Olumlu İfade (İfade Edicilik) Alt Boyutu & 0,53 \\
UKMH-DZT Karş1lı Olarak Üzüntü Alt Boyutu & 0,71 \\
UKMH-DZT Karş1lik Olarak Neşe Alt Boyutu & 0,52 \\
UKMH-DZT Genel Toplam Puanı & 0,61 \\
\hline ÇBASDÖ Aile Alt Boyutu & $-0,43^{* * *}$ \\
ÇBASDÖ Arkadaş Alt Boyutu & $-0,00$ \\
ÇBASDÖ Özel Bir İnsan Alt Boyutu & $-0,37^{* * *}$ \\
ÇBASDÖ Genel Toplam Puanı & $-0,19^{* * *}$ \\
\hline
\end{tabular}

\section{$* * * \mathrm{p}<0,001$}

Çalışmada sonraki işlem olarak, yalnızlığın, durumluk kaygı, sürekli kayg1, depresyon, algılanan sosyal destek ve duygusal zeka ile yordanması için çoklu doğrusal regresyon analizi yapılmıştır. Analiz sonucunda kurulan model istatistiksel olarak anlamlı bulunmuştur; $R^{2}=0,66$; $F(13,438)=63,460 ; p<0,001$. Sonuca göre,modele alınan değişkenler UCLA Yalnızlık Ölçeği toplam puanının $\% 66,0$ 'lık kısmını açıklamaktadır. Sonuçlar incelendiğinde, Durumluk Kayg1 Ölçeği $(\mathrm{t}=-2,041$; $p<0,05)$, Sürekli Kaygı Ölçeği $(t=3,315 ; p<0,01)$, CES Depresyon Ölçeği $(\mathrm{t}=8,323 ; \mathrm{p}<0,001), \quad \mathrm{UKMH}$ Duygusal Zeka Testi Olumlu İfade (İfade Edicilik) alt boyutu $(\mathrm{t}=-2,623$; $\mathrm{p}<0,01)$ ve Çok Boyutlu Algılanan alt boyut toplam puanları için 0,88 ile 0,94 arasında değişen iç tutarlılık güvenirlik katsayıları elde edilmiştir. Daha sonra, UCLA Yalnızlık Ölçeği ile kullanılan diğer ölçekler arası korelasyon katsayıları hesaplanmış ve UCLA Yalnızlık Ölçeği toplam puanının, Durumluk Kaygı Ölçeği ile 0,53, Sürekli Kaygı Ölçeği ile 0,60, CES Depresyon Ölçeği ile 0,68, UKHM Duygusal Zeka Testi genel toplam puanı ile $-0,49$ ve Çok Boyutlu Algılanan Sosyal Destek Ölçeği genel toplam puanı ile $-0,48$ düzeyinde ilişkili olduğu görülmüştür. Ayrıca, UKHM Duygusal Zeka Testi alt boyut toplam puanları için $-0,19$ ile $-0,52$ arasında, Çok Boyutlu Duygusal Zeka Testi alt boyut toplam puanları için $-0,23$ ile $-0,58$ arasında değișen korelasyon katsayıları hesaplanmıștır (Tablo 1).

Tablo 2. Tüm Grupta UCLA Yalnızlık Ölçeği Toplam Puanının Regresyon Analiziyle Yordanması

\begin{tabular}{|c|c|c|c|c|}
\hline$n=439$ & $\beta$ & $\mathrm{T}$ & $\mathrm{R} 2$ & $\mathrm{~F}$ \\
\hline Durumluk Kaygı Ölçeği & 0,078 & $2,041^{*}$ & & \\
\hline Sürekli Kaygi Ölçeği & 0,150 & $3,315^{* *}$ & & \\
\hline CES Depresyon Ölçeği & 0,358 & $8,323 * * *$ & & \\
\hline UKMH-DZT Duygulara Yaklaşım Alt Boyutu & $-0,053$ & $-1,434$ & & \\
\hline UKMH-DZT Duygu Temelli Karar Verme Alt Boyutu & 0,008 & 0,276 & & \\
\hline UKMH-DZT Empatik İlgi Alt Boyutu & $-0,062$ & $-1,791$ & & \\
\hline UKMH-DZT Olumsuz İfade (İfade Edicilik) Alt Boyutu & $-0,042$ & $-1,290$ & 0,660 & $63,460 * * *$ \\
\hline UKMH-DZT Olumlu İfade (İfade Edicilik) Alt Boyutu & $-0,109$ & $-2,623 * *$ & & \\
\hline UKMH-DZT Karşılık Olarak Üzüntü Alt Boyutu & $-0,042$ & $-1,129$ & & \\
\hline UKMH-DZT Karşılık Olarak Neşe Alt Boyutu & $-0,049$ & $-1,254$ & & \\
\hline ÇBASDÖ Aile Alt Boyutu & 0,020 & 0,484 & & \\
\hline ÇBASDÖ Arkadaş Alt Boyutu & $-0,278$ & $-6,594 * * *$ & & \\
\hline ÇBASDÖ Özel Bir İnsan Alt Boyutu & 0,027 & 0,818 & & \\
\hline
\end{tabular}

$* \mathrm{p}<0,05 ; * * \mathrm{p}<0,01 ; * * * \mathrm{p}<0,001$

Sosyal Destek Ölçeği Arkadaş alt boyutunun $(t=-6,594$; $\mathrm{p}<0,001)$ istatistiksel olarak anlamlı bir şekilde modelde yer aldığ 1 görülmektedir. Buna karşın, UKMH Duygusal Zeka Testi'nin Duygulara Yaklaşım $(\mathrm{t}=-1,34 ; \mathrm{p}>0,05)$, Duygu Temelli Karar Verme $(\mathrm{t}=0,276 ; \mathrm{p}>0,05)$, Empatik İlgi $(\mathrm{t}=-1,791 ; \mathrm{p}>0,05)$, Olumsuz İfade $(\mathrm{t}=$ $1,290 ; \mathrm{p}>0,05)$, Karşıllklı Olarak Üzüntü $(\mathrm{t}=-1,129$; $p>0,05)$ ve Karşılıklı Olarak Neşe $(t=-1,254 ; p>0,05)$ alt boyutları ile Çok Boyutlu Algılanan Sosyal Destek Ölçeği'nin Aile $(t=0,484 ; p>0,05)$ ve Özel Bir İnsan $(t=$ $0,818 ; p>0,05)$ alt boyutları UCLA Yalnızlık Ölçeği toplam puanının yordanması için kurulan modelde yer almamıştır (Tablo 2).

Daha sonra, UCLA Yalnızlık Ölçeği toplam puanı, her bir sosyo-demografik değişken grubunda ayrı ayrı olacak şekilde çoklu doğrusal regresyon analiziyle yordanmıştır.
Farkl1 sosyo-demografik gruplarda elde edilen yordama yüzde değerleri tablo 3'te verilmiştir. Yapılan yordama işlemi sonucunda UCLA Yalnızlık Ölçeği toplam puanını 
açıklama yüzdesi açısından en düşük yüzde değeri $(\% 62,1)$ aynı evde iki ve daha az sayıda kişiyle birlikte yaşadığını bildiren grupta elde edilirken, en yüksek yüzde değeri $(\% 77,2)$ aynı evde beş ve daha fazla sayıda kişiyle birlikte yaşadığını bildiren grupta elde edilmiştir.

Tablo 3. UCLA Yalnızlık Ölçeği Puanının Sosyo-demografik Bağımsız Değişken Gruplarında Yordanma Oranları

\begin{tabular}{lll}
\hline Sosyo-demografik Değişkenler & Gruplar & $\mathrm{R}^{2}$ \\
\hline \multirow{2}{*}{ Cinsiyet } & Kadın & 0,705 \\
& Erkek & 0,638 \\
Eğitim Düzeyi & Lise ve Altı & 0,754 \\
& Üniversite & 0,651 \\
& Öğrenci & 0,672 \\
Gelir Getiren Bir İşte Çalışma Durumu & Çalışan & 0,696 \\
& Çalışmayan & 0,712 \\
Gelir Durumu & Kötü & 0,767 \\
& Orta & 0,657 \\
& İyi & 0,714 \\
Birlikte Yaşanılan Kişi Sayısı & 2 ve daha az sayıda kişi & 0,621 \\
& 3 Kişi & 0,730 \\
Yaşanılan Yer & 4 Kişi & 0,755 \\
& 5 ve daha fazla sayıda kişi & 0,772 \\
& il / Büyükşehir & 0,671 \\
\end{tabular}

Çalışmada son aşama olarak bütün sosyo-demografik değişken grupları bir arada alınarak UCLA Yalnızlık Ölçeği toplam puanı açısından ANOVA ile karşılaştırılmıştır. Elde edilen sonuçlara göre, cinsiyet $(\mathrm{F}(1,371)=0,193 ; \mathrm{p}>0,05)$, eğitim düzeyi $(\mathrm{F}(1,371)=$ $0,641 ; \mathrm{p}>0,05)$, medeni durum $(\mathrm{F}(1,371)=0,512$; $\mathrm{p}>0,05)$, çalışma durumu $(\mathrm{F}(2,371)=0,032 ; \mathrm{p}>0,05)$,

Tablo 4. Sosyo-demografik Değiş̧en Gruplarının UCLA Yalnızlık Ölçeği Toplam Puanı Açısından ANOVA ile Karşılaştırma Sonuçları

\begin{tabular}{|c|c|c|}
\hline Değişkenler & $\mathrm{F}$ & Kısmi $\eta^{2}$ \\
\hline Ana Etki & 1,236 & 0,164 \\
\hline Cinsiyet ( 2 grup) & 0,193 & 0,001 \\
\hline Eğitim Düzeyi (2 grup) & 0,641 & 0,002 \\
\hline Medeni Durum (2 grup) & 0,512 & 0,001 \\
\hline Çalışma Durumu (3 grup) & 0,032 & 0,000 \\
\hline Gelir Durumu (3 grup) & 0,768 & 0,004 \\
\hline Birlikte Yaşanılan Kişi Sayısı (4 grup) & 2,162 & 0,017 \\
\hline Yaşanılan Yer (2 grup) & 0,424 & 0,001 \\
\hline Cinsiyet x Eğitim Durumu & $7,848 * *$ & 0,021 \\
\hline Cinsiyet x Medeni Durum & 0,485 & 0,001 \\
\hline Cinsiyet $x$ Çalışma Durumu & 1,456 & 0,008 \\
\hline Cinsiyet x Gelir Durumu & 0,976 & 0,005 \\
\hline Cinsiyet x Birlikte Yaşanılan Kişi Sayısı & 1,283 & 0,010 \\
\hline Cinsiyet x Yaşanılan Yer & 0,225 & 0,001 \\
\hline Eğitim Düzeyi x Medeni Durum & 0,175 & 0,000 \\
\hline Eğitim Düzeyi x Çalışma Durumu & 0,147 & 0,001 \\
\hline Eğitim Düzeyi x Gelir Durumu & 0,836 & 0,004 \\
\hline Eğitim Düzeyi x Birlikte Yaşanılan Kişi Sayısı & 2,516 & 0,020 \\
\hline Eğitim Düzeyi x Yaşanılan Yer & 0,268 & 0,001 \\
\hline Medeni Durum x Çalışma Durumu & 0,395 & 0,002 \\
\hline Medeni Durum x Gelir Durumu & 0,590 & 0,002 \\
\hline Medeni Durum x Birlikte Yaşanılan Kişi Sayısı & 1,434 & 0,008 \\
\hline Medeni Durum x Yaşanılan Yer & 0,837 & 0,002 \\
\hline Çalışma Durumu x Gelir Durumu & 0,804 & 0,009 \\
\hline Çalışma Durumu x Birlikte Yaşanılan Kişi Sayısı & 0,325 & 0,005 \\
\hline Çalışma Durumu x Yaşanılan Yer & 0,681 & 0,004 \\
\hline Gelir Durumu x Birlikte Yaşanılan Kişi Sayısı & 1,404 & 0,022 \\
\hline Gelir Durumu x Yaşanılan Yer & 1,109 & 0,006 \\
\hline Birlikte Yaşanılan Kişi Sayısı x Yaşanılan Yer & 1,120 & 0,009 \\
\hline
\end{tabular}

gelir durumu $(\mathrm{F}(2,371)=0,768 ; \mathrm{p}>0,05)$, birlikte yaşanılan kişi sayısı $(\mathrm{F}(3,371)=2,162 ; \mathrm{p}>0,05)$ ve yaşanılan yere göre oluşturulan grupların $(\mathrm{F}(1,371)=$ $0,424 ; p>0,05)$ UCLA Yalnızlık Ölçeği toplam puan ortalamaları arasında istatistiksel olarak anlamlı farklılık yoktur.
Ayrıca, sosyo-demografik değişkenlere göre oluşturulan grupların birbirleri üzerindeki dağılımlarının UCLA Yalnızlık Ölçeği toplam puanı açısından farklılık gösterip göstermediğini belirlemek amacıyla değişkenler arası etkileşimler incelenmiş, cinsiyet grupları ile eğitim düzeyi grupları birlikte alındığında UCLA Yalnızlık Ölçeği toplam puanı açısından gruplar arasında anlamlı düzeyde bir etkileşim olduğu $(\mathrm{F}(1,371)=7,848 ; \mathrm{p}<0,01$; 
kısmi $\left.\eta^{2}=0,021\right)$ görülmüştür. Bu sonuca göre, kadın grupta eğitim düzeyi lise ve altı grubun yalnızlık puanları, üniversite mezunu veya öğrencisi grubun yalnızlık puanlarından daha yüksektir. Erkek grupta ise durum tam tersi yöndedir ve eğitim düzeyi lise ve altı grubun yalnızlık puanları, üniversite mezunu veya öğrencisi grubun yalnızlık puanlarından daha düşüktür (Şekil 1). Diğer sosyo-demografik değişken grupları arasında ise yalnızlık puanı açısından etkileşim gözlenmemiştir (Tablo 4).

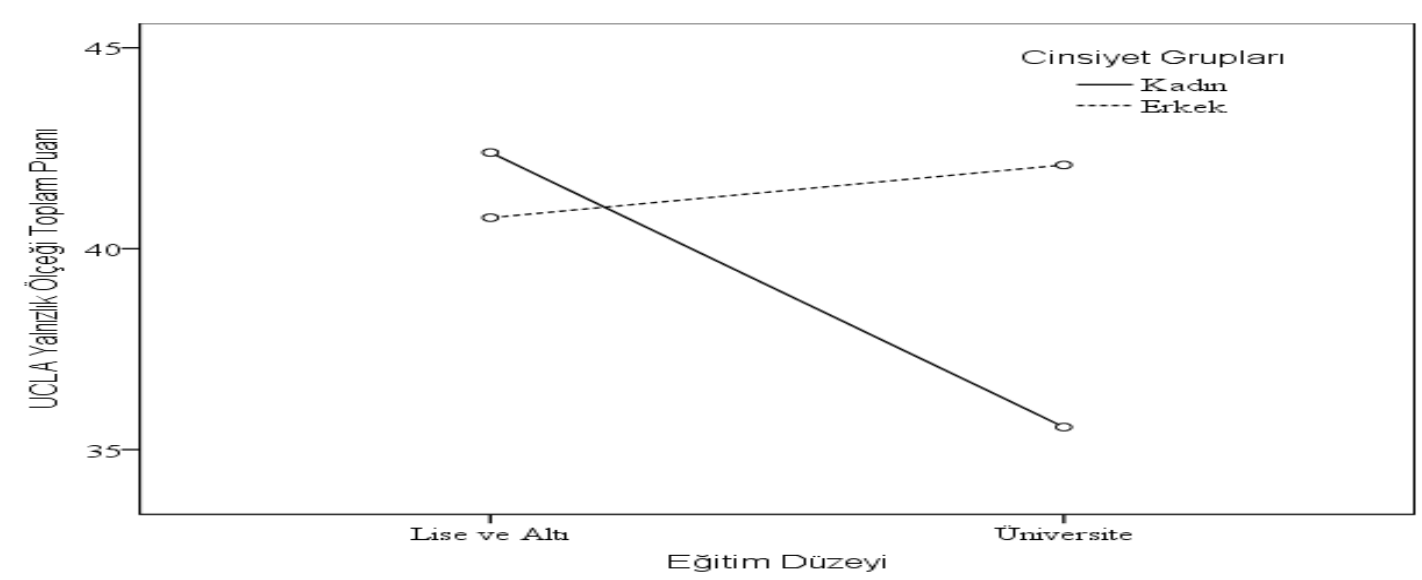

Şekil 1. UCLA Yalnızlık Ölçeği Toplam Puanı Açısından Cinsiyet ile Eğitim Düzeyi Gruplarının Karşılaştırma Sonuçları

\section{Tartışma}

Sosyal izolasyon ve olumsuz duygular ile belirginleşen yalnızlık olgusunu açıklamak üzere yürütülen araştırmaların baskın olarak çocukluk, ergenlik ve ileri yetişkinlik / yaşlılık dönemlerine odaklandığı, buna karşın genç yetişkinlik dönemine yönelik betimsel çalışmaların yetersiz olduğu görülmektedir (Besevegis ve Galanaki, 2010; Cooper, Balandin ve Trembath, 2009; Demir ve Tarhan, 2001; Eskin, 2001; Houghton ve ark., 2014; Kang, ve ark., 2018; Ozsaker ve ark., 2015; Rokach, 2005). Bu doğrultuda bu çalışma 18-25 yaşları arasındaki genç yetişkin grupta depresyon, kaygı, algılanan sosyal destek ve duygusal zekanın, yalnızlığı ne oranda açıkladığını belirlemek ve sosyo-demografik özelliklerin yalnızlık ile ilişkisini incelemek amacıyla yürütülmüştür.

Bu amaçla, çalışmada önce yalnızlık ile depresyon, kaygı, algılanan sosyal destek ve duygusal zeka arasındaki ilişkiler incelenmiş, yalnızlığın en güçlü ilişkiyi depresyon $(r=0,68)$ ve kaygı $(r=0,60)$ ile gösterdiği belirlenmiştir. Bununla birlikte, çalışmanın temel amacını karşılamak üzere, yalnızlık toplam puanının yordanması için kurulan regresyon modeline dahil edilen bağımsız değişkenlerde (duygusal zeka, kaygı, depresyon ve algılanan sosyal destek) meydana gelen değişimlere bağlı olarak yalnızlık puanlarının ne şekilde değiştiği incelendiğinde, genç yetişkinlerde yalnızlığın açıklamasında depresyonun katkısının $(\beta=0,358)$ diğer değişkenlere oranla daha yüksek olduğu görülmüştür. Yalnızlık, depresyon ve kaygı semptomlarının önemli ölçüde benzerlik gösterdiği ve çalışmada yalnızlığ 1 değerlendirmeye yönelik olarak kullanılan ölçme aracının büyük oranda çökkün duygu duruma ilişkin ifadeler içerdiği göz önünde bulundurulduğunda (Durak ve SenolDurak, 2010; Mushtaq ve ark., 2014), bu çalışmada, yalnızlığın en güçlü ilişkiyi depresyon ve kaygı ile göstermiş olması ve yalnızlığın yordanması işleminde depresyon ve kaygının ön plana çıkmış olması beklenen yönde bir sonuç olmuştur.
Bunun yanı sıra, duygusal zeka ile yalnızlık arasındaki ilişkilerin incelendiğgi çalışmalarda, iki olgu arasında negatif yönde bir ilişki bulunduğu ve duygusal zeka düzeyi arttıkça algılanan yalnızlık düzeyinin azaldığı bildirilmektedir (Lee ve Ko, 2018; Saklofske, Austin ve Minski, 2003). Benzer şekilde bu çalışmada da yalnızlığın duygusal zeka ile negatif yönde iliş̧kili olduğu görülmüştür. Bununla birlikte UKMH Duygusal Zeka Testi alt boyutları arasında, yalnızlık ile en güçlü ilişkiyi Olumlu İfade Edicilik alt boyutunun $(r=-0,51)$ gösterdiği belirlenmiştir. Ayrıca, yalnızlığı açıklamak amacıyla yapılan yordama işleminde de duygusal zeka boyutları arasından yalnızca olumlu ifade edicilik alt boyutunun modelde anlamlı olarak yer aldığı görülmüştür. $\mathrm{Bu}$ boyutun, pozitif duyguları ifade etme ve diğer insanlarla paylaşma becerisini ölçtüğü göz önünde bulundurulduğunda (Tatar, Saltukoğlu, Tok ve Bender, 2016), bu sonuçlar açıkça anlaşılır nitelikte görünmektedir.

Çalışmada ikincil bir amaç olarak sosyo-demografik değişkenlerin yalnızlık ile ilişkisi incelenmiştir. Bu doğrultuda önce her bir sosyo-demografik değişken için aynı işlemler yürütülerek regresyon analizi tekrarlanmıştır. Bu yolla, sosyo-demografik değişkenlere göre oluşturulan gruplar için elde edilen açıklama yüzdeleri incelenerek regresyon analizine alınan değişkenlerin, hangi grupta daha etkili sonuçlar ortaya koyduğu belirlenmeye çalışılmıştır. Daha sonraki işlem olarak ise sosyo-demografik değişken grupları bir arada alınarak yalnızlık düzeyi açısından çok yönlü varyans analiziyle karşılaştırılmıştır. Sonuçlara göre, depresyon, kayg1, algılanan sosyal destek ve duygusal zeka, yalnızlık toplam puanını bütün sosyo-demografik değişken gruplarında \%62,1 ile \%77,2 arasında değişen oranlarla açıklamaktadır. Bununla birlikte, kadın grup için erkek gruba oranla, eğitim düzeyi lise ve altı olan grup için eğitim düzeyi üniversite olan gruba oranla, gelir getiren bir işte çalışmayan grup için gelir getiren bir işte çalışan gruba oranla, gelir getiren bir işte çalışan grup için öğrencilerden oluşan gruba oranla, gelir durumu kötü 
olan grup için gelir durumu iyi olan gruba oranla, gelir durumu iyi olan grup için gelir durumu orta düzeyde olan gruba oranla, yaşamının büyük bir bölümünü il veya büyükşehirde geçiren grup için yaşamının büyük bir bölümünü kasaba, ilçe veya köyde geçiren gruba oranla daha yüksek açıklama yüzdeleri elde edilmiştir. Ayrıca, katılımcıların aynı evde birlikte yaşadıkları kişi sayısına bağlı olarak oluşturulan gruplar için gerçekleştirilen işlemlerde, kişi sayısı arttıkça yalnızlığın yordanmasında elde edilen açıklama yüzdelerinin de arttığı görülmüştür. Grup karşılaştırmaları için yapılan varyans analizi sonuçlarında ise sosyo-demografik grupların yalnızlık düzeyleri arasında farklılık bulunmamıştır. Bunun yanı sıra, sosyo-demografik değişkenlerin yalnızlık üzerindeki ortak etkileri incelenmiş ve cinsiyet ve eğitim düzeyi gruplarının birbirleri üzerindeki dağılımlarının ölçülen özelliğin (yalnızlık) düzeyi açısından farklılaştığ görülmüştür. Etkileşim sonucuna göre, kadın grubunda, üniversite ögrencisi veya mezunu olan grubun yalnızlık puanlarının, lise ve altı düzeydeki eğitim grubundan daha düşük olduğu, buna karşın erkeklerde ise durumun tam tersi yönde olacak şekilde üniversite öğrencisi ve ya mezunu olan grubun yalnızlık puanlarının lise ve altı düzeydeki eğitim grubundan daha yüksek olduğu izlenmiştir.

\section{Sonuç ve Öneriler}

Çalışma bulguları genel olarak değerlendirildiğinde, sosyo-demografik bağımsız değişkenlerin yalnızlık ile ilişkisini belirlemek amacıyla iki farklı istatistiksel tekniğin birlikte kullanılmasının, genç yetişkinlerde yalnızlığın betimlenmesine yönelik daha detaylı sonuçlar elde edilmesine olanak sağladığı görülmektedir. Bu bağlamda, varyans analizi, gruplar arasında yalnızlık düzeyi açısından farklılık olup olmadığının belirlenmesinde ve sosyo-demografik grupların yalnızlık üzerindeki ortak etkilerinin ortaya konulmasında etkili olmuştur. Genç yetişkinlerde yalnızlığın ilgili değişkenlerle yordanmasında, regresyon analizinin her bir grupta ayr1 ayr1 tekrarlanmas1 ise sosyo-demografik değişkenlerin etkisinin ve öneminin gösterilmesinde etkili olmuştur. Diğer taraftan, çalışma bulgularından hareketle, olgunun değerlendirilmesinde, ölçülen özellik (yalnızlık) açısından depresyon veya kaygı gibi yapılarla örtüşme göstermeyen alternatif ölçme araçlarının kullanılmasının, genç yetişkinlerde yalnızlığın daha iyi anlaşılmasına katkı sağlayacağı düşünülmektedir. Bu doğrultuda, yalnızlığın ölçümünde, büyük oranda olumsuz duygulara yer veren ve çökkün duyguduruma yönelik ifadeler içeren ölçme araçları yerine, yapının mutluluk, iyi oluş gibi farklı yönlerini de yansıtan ve ölçmeye olanak tanıyan farklı ölçme araçlarının kullanılmasının, olgunun farklı açılardan incelenmesini sağlayacağı düşünülmektedir. Ayrıca, bu çalışmada, ilgili diğer çalışmalardan farklı olarak, diğer duygusal zeka ölçeklerine oranla daha az sayıda çalışmada kullanıldığı görülen ve duygusal zekanın farklı boyutlarını değerlendirmeye olanak tanıyan bir ölçme aracının (UKMH Duygusal Zeka Testi) kullanılmış olması, hem çalışmanın özgün yanını hem de alan yazındaki ilgili çalışma bulgularılla karşılaştırmayı güçleştirmesi yönüyle sınırlılığını oluşturmaktadır.

$\mathrm{Bu}$ çalışmanın en büyük sınırlılığı ise yalnızlığın yordanması ve sosyo-demografik özelliklerle ilişkisinin incelenmesi işlemleri için, katılımcıların, sosyodemografik özelliklere göre oluşturulan gruplara sayıca dengeli dağılmamış olmasıdır. Diğer bir ifadeyle, bu çalışmanın katılımcıları her ne kadar cinsiyet, eğitim düzeyi, medeni durum, gelir durumu, çalışma durumu ve yaşamın büyük bir bölümünün geçirildiği yer (il / büyükşehir veya kasaba / ilçe) açısından geniş bir yelpazede yer alacak şekilde seçilmiş olsa da oluşturulan bazı gruplardaki kişi sayıları dengeli görünmemektedir. $\mathrm{Bu}$ bağlamda, genç yetişkinlerde yalnızlığın daha iyi anlaşılmasına yönelik betimsel araştırmalar doğrultusunda yapılacak uygulamalar için, hedef grubu temsil edecek ve farklı sosyo-demografik grupları yansıtabilecek daha geniş bir örneklem grubuyla çalıșılması önerilmektedir. Farklı sosyo-demografik grupların incelenmesinde özellikle farklı yaş grupların karşılaştırılması yalnızlığın anlaşılmasına, bu çalışmada yer verilmeyen farklı olgusal yapıların (örn. sosyal beceriler, kişilik özellikleri) alınması ise gençlerde yalnızlığın anlaşılmasına katkı sağlayacaktır. Ancak yöntemsel olarak da yalnızlığın incelenmesinde özellikle farklı yaklaşımların ve teorilerin test edilmesi yoluyla olgu gençlerde yeninden incelenebilir gibi görünmektedir. Özellikle genç grupta yalnızlığı açıklamaya yönelik farklı teorik yaklaşımların yol (path) analiziyle incelenmesi bu gruba yönelik farklı düzeyde bilgi sağlayacaktır. Ayrıca yine farklı sosyo-demografik grupların incelenmesi bağlamında yalnızlığın klinik ve klinik olmayan grupların karşılaştırmasına olanak verecek şekilde incelenmesi de yararlı olacaktır. Son olarak depresyon, kayg1, duygusal zeka ve sosyal destek dışında, yalnızlıkla ilişkili olduğu bilinen diğer değişkenlerin (örn. sosyal beceri, benlik saygısı, kişilik özellikleri) araştırma tasarımına dahil edilmemiş olması bu çalışmanın bir sınırlılığı olarak görünmektedir. Bu nedenle yalnızlıkla ilişkisi bağlamında daha çok sayıda değişkenin birlikte alınmasının "olgunun yordanması" sürecinin yürütülmesine daha fazla katk1 sağlayacaktır

\section{Kaynaklar}

Alpass, F. M. ve Neville, S. (2003). Loneliness, health and depression in older males. Aging and Mental Health, 7(3), 212216.

Aylaz, R., Aktürk, Ü., Erci, B., Öztürk, H. ve Aslan, H. (2012). Relationship between depression and loneliness in elderly and examination of influential factors. Archives of Gerontology and Geriatrics, 55(3), 548-554.

Barchard, K. A. (2001). Emotional and social intelligence: examining its place in the nomological network. (Unpublished doctoral dissertation), University of British Columbia, Department of Psychology, Vancouver, Canada.
Besevegis, E. ve Galanaki, E. P. (2010). Coping with loneliness in childhood. European Journal of Developmental Psychology, 7(6), 653-673.

Cooper, L., Balandin, S. ve Trembath, D. (2009). The loneliness experiences of young adults with cerebral palsy who use alternative and augmentative communication. Augmentative and Alternative Communication, 25(3), 154-164.

Daniel, K. (2013). Loneliness and depression among university students in Kenya. Global Journal of Human-Social Science: Arts and Humanities, 13(4), 11-18. 
de Jong-Gierveld, J. (1987). Developing and testing a model of loneliness. Journal of Personality and Social Psychology, 53(1), 119-128.

de Jong-Gierveld, J. (1998). A review of loneliness: concept and definitions, determinants and consequences. Reviews in Clinical Gerontology, 8(1), 73-80.

de Jong-Gierveld, J. ve van Tilburg, T. G. (2006a). Loneliness and social isolation. In D. Perlman, \& A. Vangelisti (Eds.), Cambridge handbook of personal relationships (pp. 485-500). Cambridge: Cambridge University Press.

de Jong-Gierveld, J. ve van Tilburg, T. G. (2006b). A 6-item scale for overall, emotional, and social loneliness: confirmatory tests on survey data. Research on Aging, 28(5), 582-598.

de Jong-Gierveld, J. ve van Tilburg, T. G. (2008). A shortened scale for overall, emotional and social loneliness. Tijdschrift voor Gerontologie en Geriatrie, 39(1), 4-15.

Demir, A. (1989). UCLA Yalnızlık Ölçeğinin geçerlik ve güvenirliği. Psikoloji Dergisi, 7(23), 14-18.

Demir, A. ve Tarhan, N. (2001). Loneliness and social dissatisfaction in Turkish adolescents. The Journal of Psychology, 135(1), 113-123.

Durak, M., \& Senol-Durak, E. (2010). Psychometric qualities of the UCLA Loneliness Scale-Version 3 as applied in a Turkish culture. Educational Gerontology, 36(10-11), 988-1007.

Eker, D. ve Arkar, H. (1995). Çok Boyutlu Algılanan Sosyal Destek Ölçeği'nin faktör yapısı, geçerlik ve güvenirliği. Türk Psikoloji Dergisi, 10(34), 17-25.

Eker, D., Arkar, H. ve Yaldız, H. (2001). Çok Boyutlu Algılanan Sosyal Destek Ölçeği'nin gözden geçirilmiş formunun faktör yapısı, geçerlik ve güvenirliği. Türk Psikiyatri Dergisi, 12(1), 17-25.

Eskin, M. (1993) Reliability of Turkish version of the Perceived Social Support from Friends and Family Scales, Scale for Interpersonal Behavior, and Suicide Probability Scale. Journal of Clinical Psychology, 49, 515-522.

Eskin, M. (2001). Ergenlikte yalnızlık, baş etme yöntemleri ve yalnızlığın intihar davranışı ile ilişkisi. Klinik Psikiyatri, 4(5), 511.

Fees, B. S., Martin, P. ve Poon, L. W. (1999). A model of loneliness in older adults. The Journals of Gerontology: Psychological Sciences, 54(4), 231-239.

Houghton, S., Hattie, J., Wood, L., Carroll, A., Martin, K. ve Tan, C. (2014). Conceptualising loneliness in adolescents: development and validation of a self-report instrument. Child Psychiatry and Human Development, 45(5), 604-616.

Kafetsios, K. ve Sideridis, G. D. (2006). Attachment, social support and well-being in young and older adults. Journal of Health Psychology, 11(6), 863-875.

Kang, H. W., Park, M. ve Wallace, J. P. (2018). The impact of perceived social support, loneliness, and physical activity on quality of life in South Korean older adults. Journal of Sport and Health Science, 7(2), 237-244.

Le Prevost, M., Arenas-Pinto, A., Melvin, D., Parrott, F., Foster, C., Ford, D., et al. (2018). Anxiety and depression symptoms in young people with perinatally acquired HIV and HIV affected young people in England. AIDS Care, 30(8), 1040-1049.

Lee, Y. ve Ko, Y. G. (2018). Feeling lonely when not socially isolated: social isolation moderates the association between loneliness and daily social interaction. Journal of Social and Personal Relationships, 35(10), 1340-1355.

Lykes, V. A. ve Kemmelmeier, M. (2014). What predicts loneliness? Cultural difference between individualistic and collectivistic societies in Europe. Journal of Cross-Cultural Psychology, 45(3), 468-490.
Lykes, V. A. ve Kemmelmeier, M. (2014). What predicts loneliness? Cultural difference between individualistic and collectivistic societies in Europe. Journal of Cross-Cultural Psychology, 45(3), 468-490.

Mahon, N. E., Yarcheski, A., Yarcheski, T. J., Cannella, B. L. ve Hanks, M. M. (2006). A meta-analytic study of predictors for loneliness during adolescence. Nursing Research, 55(5), 308315 .

Mushtaq, R., Shoib, S., Shah, T. ve Mushtaq, S. (2014). Relationship between loneliness, psychiatric disorders and physical health? A review on the psychological aspects of loneliness. Journal of Clinical and Diagnostic Research, 8(9), 14.

Öner, N. ve Le Compte, A. (1985). Durumluk - Sürekli Kaygl Envanteri el kitabı (2. Bask1). İstanbul: Boğaziçi Üniversitesi Yayınları.

Perlman, D. ve Peplau, L. A. (1981). Toward a social psychology of loneliness. In S. Duck \& R. Gilmour (Eds.), Personal relationships in disorder. London: Academic Press.

Perlman, D. ve Peplau, L. A. (1984). Loneliness research: a survey of empirical findings. In L. A. Peplau \& S. Goldston (Eds.), Preventing the harmful consequences of severe and persistent loneliness (pp. 13-46). Washington: U.S. Government Printing Office.

Procidano, M. E. ve Heller, K. (1983). Measures of perceived social support from friends and from family: three validation studies. American Journal of Community Psychology, 11(1), 124.

Qualter, P., Vanhalst, J., Harris, R., Van Roekel, E., Lodder, G., Bangee, M., et al. (2015). Loneliness across the life span. Perspectives on Psychological Science, 10(2), 250-264.

Radloff, L. S. (1977). The CES-D Scale: a self-report depression scale for research in the general population. Applied Psychological Measurement, 1(3), 385-401.

Rokach, A. (2001). Strategies of coping with loneliness throughout the lifespan. Current Psychology, 20(1), 3-17.

Rokach, A. (2005). The causes of loneliness in homeless youth. The Journal of Psychology, 139(5), 469-480.

Rokach, A. (2012). Loneliness updated: an introduction. The Journal of Psychology, 146(1-2), 1-6.

Russell, D. W., Cutrona, C. E., McRae, C. ve Gomez, M. (2012). Is loneliness the same as being alone? The Journal of Psychology, 146(1-2), 7-22.

Russell, D., Peplau, L. A. ve Cutrona, C. E. (1980). The Revised UCLA Loneliness Scale: concurrent and discriminant validity evidence. Journal of Personality and Social Psychology, 39(3), 472-480.

Saklofske, D. H., Austin, E. J. ve Minski, P. S. (2003). Factor structure and validity of a trait emotional intelligence measure. Personality and Individual Differences, 34(4), 707-721.

Seepersad, S. (2004). Coping with loneliness: adolescent online and offline behavior. Cyber Psychology and Behavior, 7(1), 3539.

Singh, A. ve Misralnd, N. (2009). Loneliness, depression and sociability in old age. Indian Journal of Psychiatry, 18(1), 51-55.

Spence, R., Jacobs, C. ve Bifulco, A. (2018). Attachment style, loneliness and depression in older age women. Aging and Mental Health, 1-3.

Spielberger, C. D., Gorsuch, R. L. ve Lushene, R. E. (1970). The State-Trait Anxiety Inventory (test manual). Palo Alto, California: Consulting Psychologists Press. 
Tatar, A. ve Saltukoğlu, G. (2010). CES-Depresyon Ölçeği'nin doğrulayıcı faktör analizi ve Madde Cevap Kuramı kullanımı ile Türkçe'ye uyarlanması ve psikometrik özelliklerinin incelenmesi. Klinik Psikofarmakoloji Bülteni, 20(3), 213-227.

Tiwari, S. C. (2013). Loneliness: a disease? IndianJournal of Psychiatry, 55(4), 320-322.Vanhalst, J., Luyckx, K., Raes, F. ve Goossens, L. (2012). Loneliness and depressive symptoms: the mediating and moderating role of uncontrollable ruminative thoughts. The Journal of Psychology, 146(1-2), 259-276. van Winkel, M., Wichers, M., Collip, D., Jacobs, N., Derom, C., Thiery, E., et al. (2017). Unraveling the role of loneliness in depression: the relationship between daily life experience and behavior. Psychiatry, 80(2), 104-117.

Weiss, R. S. (1973). Loneliness: the experience of emotional andsocial isolation. Cambridge, MA: MIT Press

Zimet, G. D., Dahlem, N. W., Zimet, S. G. ve Farley, G. K. (1988). The Multidimensional Scale of Perceived Social Support.Journal of Personality Assessment, 52(1), 30-41. 